\title{
The Factors Affecting Poverty Rate in Central Java Province 2018-2020
}

\author{
By \\ Solikhin \\ Badan Pusat Statistik Kabupaten Cilacap \\ Corresponding Author: solikhin@bps.go.id \\ Submission: May 19, 2021; Accepted: September 07, 2021
}

\begin{abstract}
One of the Central Java Provincial Government programs is to reduce the number of people living in poverty. The Central Java Provincial Government target in 2020 was to lower poverty rate to below ten percent. Therefore, it is necessary to determine factors affecting the poverty rate in Central Java. This study aimed to analyze the effect of the Human Development Index, total population, Gross Regional Domestic Product (GDRP), and the impact of the Covid-19 pandemic on the poverty rate in regencies/municipalities in Central Java. The study on the impact of the Covid-19 pandemic on the poverty rate in Central Java Province has never been carried out. This study was different from the previous studies. This study used panel data regression by using 2018-2020 data from Statistics Indonesia (BPS). In this study, the result of the best model selection was the random effect model. The result of this study indicated that Human Development Index (HDI) had a negative and significant effect, total population had a positive and insignificant, GRDP had a negative and significant effect, and the impact of Covid-19 pandemic had a positive and significant effect on the poverty rate.
\end{abstract}

Keywords: Impact of Covid-19, Human Development Index, Population, Poverty Rate, Gross Regional Domestic Product.

\begin{abstract}
ABSTRAK
Penurunan jumlah penduduk miskin merupakan salah satu program pemerintah Provinsi Jawa Tengah, dengan menargetkan angka kemiskinan di tahun 2020 dibawah sepuluh persen. Oleh karena itu, perlu diketahui faktor apa saja yang mempengaruhi besarnya persentase penduduk miskin di Jawa Tengah. Penelitian ini bertujuan untuk menganalisis pengaruh Indeks Pembangunan Manusia (IPM), jumlah penduduk, Produk Domestik Regional Bruto (PDRB), dan dampak pandemi Covid-19 terhadap persentase tingkat kemiskinan di kabupaten atau kotamadya di Jawa Tengah. Penelitian tentang dampak pandemi Covid-19 terhadap persentase angka kemiskinan di Provinsi Jawa Tengah belum pernah dilakukan dan menjadi keunikan dari penelitian ini dan yang membedakan dengan penelitian penelitian sebelumnya. Penelitian ini menggunakan data tahun 2018-2020 yang bersumber dari Badan Pusat Statistik (BPS) dengan menggunakan regresi data panel. Pada penelitian ini, hasil spesifikasi pemilihan model yang terbaik adalah random effect model. Hasil penelitian ini menunjukkan bahwa: Indeks Pembangunan Manusia (IPM) berpengaruh negatif dan signifikan, jumlah penduduk berpengaruh positif tetapi tidak signifikan, PDRB berpengaruh negatif dan signifikan, serta dampak pandemi Covid-19 berpengaruh positif dan signifikan terhadap persentase penduduk miskin.
\end{abstract}

Kata Kunci: Dampak Covid-19, Indeks Pembangunan Manusia, Jumlah Penduduk, Persentase Kemiskinan, Produk Domestik Regional Bruto. 


\section{INTRODUCTION}

Poverty is a global issue facing various countries worldwide. Thus, they pay attention to the issue (Todaro et al., 2000). According to (Arsyad, 1999), poverty can be broadly classified into two aspects, namely primary aspects and secondary aspects. The primary aspects of poor are assets, socio-political organizations, knowledge, and skills. Meanwhile, the secondary aspects of poor are social network, financial resources, and information. Poverty can also be interpreted as an absolute or relative condition in an area where people cannot meet their basic needs according to the prevailing values or norms (Nugroho et al., 2012). Based on data from the Statistics Indonesia (BPS), Indonesia's population in 2020 is 269.60 million people and ranks as the fourth most populous nation in the world.

Out of the 34 provinces in Indonesia, Central Java Province has 34.74 million people and is the third-most populous province in Indonesia (BPS; 2020). The large population in Central Java Province may undoubtedly cause social problems, such as poverty. The number of people living in poverty in Central Java Province in 2020 is 3.98 million people. Central Java Province has the second highest number of people living in poverty in Indonesia after East Java Province. Reducing the number of people living in poverty is one of the Central Java Provincial government programs. The government targeted to reduce the poverty rate in 2020 to 9.81 percent (Central Java Province Regional Poverty Reduction Coordination Team, 2020). Therefore, it is essential to conduct a study on poverty rate to determine factors affecting poverty rate in Central Java Province. The results of this study are essential for policymakers to identify factors that can reduce poverty rate in Central Java Province.

Several previous studies on poverty rate in Central Java Provinc includes Central Java Province poverty data modeling using fixed-effect spatial Durbin model (Alvitiani et al., 2019), spatial analysis of the effect of unemployment rate on poverty in Indonesia: a case study of Central Java Province (Rahmawati et al., 2015), MGWR modeling on poverty levels in Central Java Province (Darsyah et al., 2015), multidimensional poverty analysis in Central Java Province 2011-2013 (Indriani and Setiyono, 2018), analysis of the effect of per capita income, unemployment rate, HDI and population growth on poverty in Central Java in 2009-2013 (Fadlillah et al., 2016) and analysis of factors affecting poverty: a case studies in Banjarnegara, Cilacap, Purbalingga, Kebumen, and Banyumas Regencies (Wijaya $\mathrm{H}$ et al., 2020).

Population is a fundamental problem because if the population grows rapidly and uncontrollably, it can hamper economic development goals, namely the welfare of the people and poverty reduction (Saputra W.A, 2011). Didu S and Fauzi F (2016) and Silastri N (2017) indicated that the population significantly affects poverty.

GRDP is the gross added value of all goods and services produced in the geographic boundaries of a country arising from various economic activities within a specific period (BPS, 2020). Total GRDP is an indicator to calculate economic growth. Economic growth provides an opportunity for a region to overcome various problems, including poverty. The poverty rate can be reduced if the GRDP increases in real terms. Susanty (2013) indicated that the GRDP negatively correlates with poverty.

The HDI provides an overview of the development of a decent life with three components, namely health, education, and purchasing power parity. Pratama (2014) stated that HDI has a negative effect on poverty. The previous study conducted by Wijaya $\mathrm{H}$ et al. (2020) also stated that GRDP and HDI negatively correlate with poverty rates.

Another factor causing the increase in poverty is disasters or disease outbreaks. The Covid-19 pandemic has begun to enter Indonesia since 2020. Due to the increasing number of positive cases with more evenly distributed areas throughout Indonesia, the President of the Republic of Indonesia has declared the Covid-19 pandemic as a non-natural national disaster. A study on the impact of the covid-19 pandemic on poverty in Indonesia has been carried out by Tarigan $\mathrm{H}$ et al. (2020). They stated that the Covid-19 pandemic had caused an increase in poverty rate in most provinces in Indonesia. This study used data from provincial level and from March 2020. The effect of the Covid-19 pandemic has not ended as of the end of 2020. Therefore, the effect of the Covid-19 pandemic in Central Java Province 2020 can be seen by looking at the conditions in the regencies/municipalities in 2018-2020.

The previous studies on poverty were limited until 2019. The study on poverty in Central Java Province in 2018-2020 has not been carried out. Thus, it was essential to conduct a study on poverty 
in Central Java Province in 2018-2020. This study aimed to analyze poverty in Central Java Province in 2018-2020 using a panel data regression approach. The variables used in this study are HDI, GRDP, and total population. This study also determined whether the coronavirus disease (Covid-19) pandemic in 2020 significantly affects poverty in Central Java Province.

\section{METHODS}

The scope of this study was all 35 regencies/municipalities in Central Java Province. It used the data series from 2018 to 2020. Hence, it used a total of 105-panel data as a combination of cross-section and time-series data. This study used the panel data regression method using secondary data from Statistics Indonesia (BPS). The dependent variable is poverty rate. Meanwhile, the independent variables are $\mathrm{HDI}$, total population, GRDP, and the impact of the Covid-19 pandemic.

The following is the definition used in this study: (1) The poverty rate is the percentage of poor people whose income is below the poverty line in the regencies/municipalities in Central Java Province (in percentage units). (2) HDI is an indicator in determining the quality of human development. Human development is a process of enlarging the choices of people. (3) Population is people who live in geographical areas in regencies/municipalities in Central Java Province for six months or more or those who live for less than six months but aim to settle down. The total population used in this study is the total population of the regency/municipality sourced from BPS (people). (4) GRDP is the total value of goods and services produced in an area at a specified time (in units of million Rupiah). In other words, GRDP is the amount of gross value added arising from all economic sectors in a region. Value added is the value-added from the combination of production factors and raw materials in the production process. Meanwhile, the calculation of added value is the value of production (output) minus intermediate costs. Gross value added includes the components of factor income (wages and salaries, interest, land rent, and profits), depreciation, and net indirect taxes. The GRDP (millions of Rupiah) was obtained by adding up the gross added value of each sector and the gross added value of all the sectors. (5) The impact of Covid-19 is the year or period experiencing the Covid-19 pandemic, in this case, 2020.

According to Widarjono (2009), panel data combines time-series data and cross-sectional data (individual). The formulation of the panel data model is as follows:

$$
\text { PERCENTAGE OF POVERTY }{ }_{i t}=\beta_{0}+\beta_{1} \text { HDI } I_{i t}+\beta_{2} \text { LNPOPULATION }_{i t}+\beta_{3} \text { GRDP }_{i t}+\beta_{4} \text { DCOVID } 19_{i t}+e_{i t}
$$
Notation:

$i$

$t$

PERCENTAGE OF POVERTY

$\beta_{0}$

$\beta_{1}, \beta_{2}, \ldots, \beta_{4}$

$H D I_{i t}$

LNPOPULATION $_{i t}$

DCOVID 19 it

$\varepsilon_{i t}$
: the cross-section data unit

: time-series data units

: poverty rate of regency/municipality i for the $t$ time period

: constant value

: coefficient value

: HDI value of regency/municipality i time period $t$

: total population of regency/municipality $\mathrm{i}$ time period $\mathrm{t}$

: impact of the regency/municipality i Covid-19 pandemic period $t$

: the i-th cross-section unit regression error for the t-time period;

The followings are the steps of data analysis in this study: (1) Estimating the panel data regression model using three models, namely the Common Effect Model (CEM), Fixed Effect Model (FEM), and Random Effect Model (REM). (2) Performing Chow test. If the selected model is CEM, then continue to step 4. Meanwhile, if the FEM is selected, continue to step 3. (3) Performing the Hausman test. If the REM is selected, continue to step 4. Meanwhile, if the FEM is selected, continue to step 5. (4) Performing the Lagrange Multiplier test to select the selected CEM or REM. (5) Performing classical 
assumption test on the selected model. (6) Interpreting the final panel data regression model. (7) Performing parameter significance test, which includes simultaneous test and partial test.

A model selection specification test is carried out from the three estimation models to determine the best model. There are three model specification tests: the Chow test, Hausman test, and Lagrange Multiplier test. Figure 1 shows the stage of selecting the best model among CEM, FEM, and REM.

\begin{tabular}{|c|c|c|}
\hline $\begin{array}{c}\text { Stage 1: } \\
\text { Chow test for } \\
\text { choosing the best model } \\
\text { between CEM and FEM }\end{array}$ & $\begin{array}{c}\text { Stage 2: } \\
\text { Hausman test for } \\
\text { choosing the best model } \\
\text { between REM and FEM }\end{array}$ & $\begin{array}{c}\text { Stage 3: Test } \\
\text { Lagrange Multiplier } \\
\text { for choosing the best model } \\
\text { between CEM and REM }\end{array}$ \\
\hline
\end{tabular}

Figure 1. The stages of selecting the best model among CEM, FEM, and REM

\section{RESULTS AND DISCUSSION}

Based on Table 1, the poverty rate in Central Java in 2019 is $10.8 \%$ or decreases by $0.52 \%$ compared to 2018. Meanwhile, in 2020, it is the opposite. The percentage increases by $0.61 \%$ compared to 2019. The increase in poverty rate will undoubtedly be a serious concern for the government, especially the Central Java Provincial Government because one of the government's programs is to reduce the poverty rate each year. The HDI and total population of Central Java in 2020 increase by 0.14 and $0.54 \%$ compared to 2019 . Meanwhile, the GRDP in 2020 decreases by $2.65 \%$ compared to 2019.

Table 1. Poverty Rate, HDI, Population and GRDP in Central Java 2018 - 2020

\begin{tabular}{lccc}
\hline & \multicolumn{3}{c}{ Year } \\
& 2018 & 2019 & 2020 \\
\hline Poverty Rate (\%) & 11.32 & 10.8 & 11.41 \\
HDI & 71.12 & 71.73 & 71.87 \\
Total Population & $34,358.5$ & $34,552.5$ & $34,738.2$ \\
GRDP & $941,091,143.9$ & $991,913,118.5$ & $965,629,085.1$ \\
\hline
\end{tabular}

Source: BPS, 2020

The panel data regression model can be estimated using three models, namely the CEM, FEM, and REM. Table 2 shows the results for the three models.

Table 2. Estimation Results of Common Effect, Fixed Effect, and Random Effect Models

\begin{tabular}{ccccccc}
\hline Dependent Variable & \multicolumn{5}{c}{ Poverty Rate } \\
\hline Independent Variable & $\begin{array}{c}\text { Common } \\
\text { Effect } \\
\text { Model }\end{array}$ & P-Value & $\begin{array}{c}\text { Fixed Effect } \\
\text { Model }\end{array}$ & P-Value & $\begin{array}{c}\text { Random Effect } \\
\text { Model }\end{array}$ & P-Value \\
\hline C & 41.47420 & 0.0001 & 105.0896 & 0.0812 & 57.34791 & 0.0027 \\
HDI & -0.410788 & 0.0000 & -0.360452 & 0.0035 & -0.452933 & 0.0000 \\
LNPOPULATIO & 1.586235 & 0.0973 & -0.149834 & 0.9756 & 2.144701 & 0.2627 \\
N & -1.354118 & 0.0969 & -3.929637 & 0.0077 & -2.565675 & 0.0002 \\
LNGRDP & 0.516293 & 0.3301 & 0.528203 & 0.0000 & 0.536672 & 0.0000 \\
DCOVID19 & & & & & & \\
\hline
\end{tabular}

Source: Data Processing Results

The Chow test is used to choose the best estimation model between the CEM and FEM. The Chow test results in Table 3 show that $p$-value is 0.0000 or smaller than $\alpha=0.05$. It indicates that $\mathrm{H}_{0}$ is rejected, meaning that the best estimation model is FEM. 
Table 3. Chow Test Results

\begin{tabular}{lccc}
\hline Effects Test & Statistic & d.f. & P-Value \\
\hline Cross-section F & 782.763140 & $(34.66)$ & 0.0000 \\
Cross-section Chi-square & 630.211340 & 34 & 0.0000 \\
\hline
\end{tabular}

Source: Data Processing Results

The next step is to conduct the Hausman test to determine the best estimation model between the FEM and the REM. The result in Table 4 shows that $p$-value is 1.0000 or larger than $\alpha=0.05$. It indicates that $\mathrm{H}_{0}$ is accepted, meaning that the best estimation model is the REM.

Table 4. Hausman Test Results

\begin{tabular}{lccc}
\hline Test Summary & Chi-Sq. Statistic & Chi-Sq. d.f. & P-Value \\
\hline Cross-section random & 0.000000 & 4 & 1.0000 \\
\hline
\end{tabular}

Source: Data Processing Results

The process of selecting the best model is continued by conducting the Lagrange Multiplier test. This test aims to choose the best estimation model between the CEM and the REM. Table 5 shows the results of the test. In the Lagrange Multiplier test results, Prob. Breusch-Pagan for both columns has a value of 0.000 , and it is smaller than $\alpha=0.05$. Therefore, it can be concluded that $\mathrm{H}_{0}$ is rejected, meaning that the best estimation model is the REM.

Table 5. Lagrange Multiplier Test Results

\begin{tabular}{lccc}
\hline & & Test Hypothesis & \\
\hline & Cross-section & Time & Both \\
\hline Breusch-Pagan & 104.0684 & 1.464858 & 105.5332 \\
& $(0.0000)$ & $(0.2262)$ & $(0.0000)$
\end{tabular}

\section{Source: Data Processing Results}

From all the model selection tests, it is found that the REM is the best model. After obtaining the best estimation model, the classical assumptions test is conducted. The method developed by Jarque-Bera can formally detect the residual normality test. Figure 2 shows the result of the JarqueBera test. The probability value is 0.340731 , greater than 0.05 . It indicates that $\mathrm{H}_{0}$ is accepted, meaning that the residuals are normally distributed. Therefore, the assumption of normality is fulfilled.

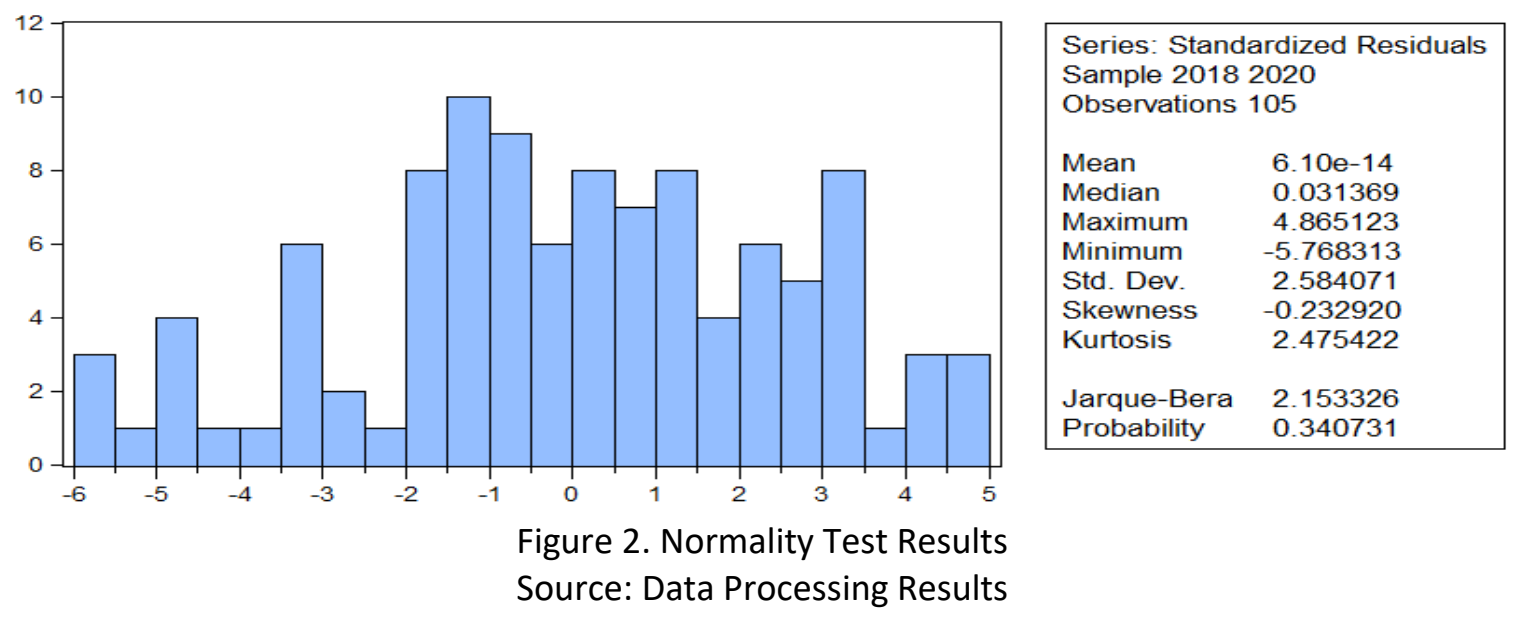

The multicollinearity can be detected by using the correlation value between independent variables. Table 5 indicates that none of the correlations between independent variables is larger than 0.8 . 
Table 5. Collinearity Between Dependent Variables

\begin{tabular}{lcccc}
\hline & HDI & LNPOPULATION & LNGRDP & DCOVID19 \\
\hline HDI & 1.000000 & -0.475932 & 0.148474 & 0.045521 \\
LNPOPULATION & -0.475932 & 1.000000 & 0.684092 & 0.007446 \\
LNGRDP & 0.148474 & 0.684092 & 1.000000 & 0.004895 \\
DCOVID19 & 0.045521 & 0.007446 & 0.004895 & 1.000000 \\
\hline
\end{tabular}

Source: Data Processing Results

Based on the results of the multicollinearity indicators above, the correlation between variables does not exceed $+/-0.8$ (Baltagi B. $H, 2005$ ). Therefore, there is no multicollinearity problem in the independent variables.

Table 6. Autocorrelation Test Results

\begin{tabular}{llll}
\hline & Weighted Statistics & \\
\hline R-squared & 0.738933 & Mean dependent var & 0.368039 \\
Adjusted R-squared & 0.728490 & S.D. dependent var & 0.300637 \\
S.E. of regression & 0.156652 & Sum squared resid & 2.453979 \\
F-statistic & 70.76078 & Durbin-Watson stat & 2.035337 \\
Prob(F-statistic) & 0.000000 & & \\
\hline
\end{tabular}

Source: Data Processing Results

The non-autocorrelation assumption is tested using the Durbin-Watson test. Table 6 shows that the Durbin-Watson stat value is 2.035337 and $d_{L}$ value $=1.6038$ and $d_{U}$ value $=1.7617$ (from the Durbin-Watson table with $\mathrm{n}=105$ and $\mathrm{k}=4)$. Because $d_{U} \leq d \leq 4-d_{U}(1.7617 \leq 2.035337 \leq 2.2383)$, it can be concluded that there is no autocorrelation in the residuals.

Table 7. Homoscedasticity Test Results

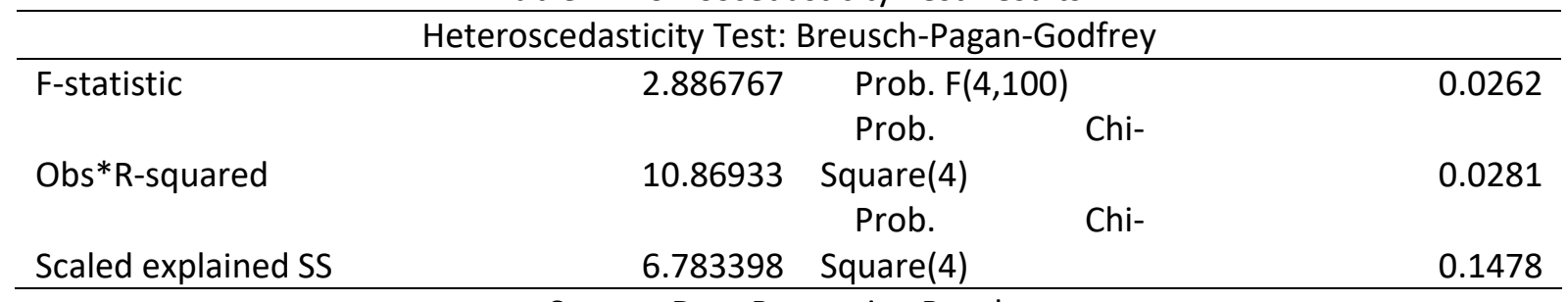

Source: Data Processing Results

Testing for the heteroscedasticity in panel regression can be carried out using the BreuschPagan-Godfrey test. Prob. Chi-Square(4) on Obs*R-squared is 0.0279 , smaller than 0.05 . Therefore, it can be concluded that $\mathrm{H}_{\mathrm{a}}$ is accepted, meaning that there is heteroscedasticity in the residuals. To overcome the heteroscedasticity problem, the REM uses robust standard errors. Thus, this study can explain further the effect of each independent variable on the dependent one. Panel data regression analysis is used to determine the effect of HDI, total population, GRDP, and the impact of the Covid19 pandemic on the poverty rate in 35 regencies/municipalities in Central Java. Table 8 shows the best estimation model of this study.

Table 8. The Output of Random Effect in Panel Data Regression Results

\begin{tabular}{lrrrr}
\hline Variable & Coefficient & Std. Error & t-Statistic & P-Value \\
\hline C & 57.34791 & 18.63699 & 3.077101 & 0.0027 \\
HDI & -0.452933 & 0.053352 & -8.489562 & 0.0000 \\
LNPOPULATION & 2.144701 & 1.904243 & 1.126275 & 0.2627
\end{tabular}




\begin{tabular}{|c|c|c|c|c|}
\hline LNGRDP & -2.565675 & 0.654460 & -3.920291 & 0.0002 \\
\hline DCOVID19 & 0.536672 & 0.062092 & 8.643136 & 0.0000 \\
\hline \multicolumn{5}{|c|}{ Weighted Statistics } \\
\hline R-squared & 0.738933 & Mean dependent var & & 0.368039 \\
\hline Adjusted R- & 0.728490 & S.D. dependent var & & 0.300637 \\
\hline S.E. of & 0.156652 & Sum squared resid & & 2.453979 \\
\hline F-statistic & 70.76078 & Durbin-Watson stat & & 2.035337 \\
\hline Prob(F-statistic) & 0.000000 & & & \\
\hline
\end{tabular}

The regression equation of random effect model is as follows:

$\hat{Y}=57.34791-0.452933 H D I+2.144701 L N P O P U L A T I O N-2.565675 L N G R D P+0.536672 D C O V I D 19$

Notation:

Y: Poverty Rate

The F-test shows a value of 0.000000 . It indicates that HDI, total population, GRDP, and the impact of Covid-9 simultaneously have a significant effect on the poverty rate. Based on the equation model, the coefficient of determination $\left(R^{2}\right)$ is $73.90 \%$, meaning that the variables of HDI, total population, GRDP, and the impact of Covid-19 can explain the variability of the poverty rate in Central Java by $73.90 \%$. In comparison, the remaining $26.1 \%$ can be explained by other variables that are not in the model.

From the partial or individual significance test results, the HDI, GRDP, and the impact of Covid19 have a probability value below 0.05 . It indicates that the HDI, GRDP, and the impact of Covid9 partially have significant effect on the poverty rate. Meanwhile, the probability of total population is 0.2627 , greater than 0.05 . It means that total population has no significant effect on the poverty rate.

The panel data regression equation shows that the HDI coefficient is -0.452933 . It means that the HDI has a negative impact on poverty rate. Every one percent increase in HDI will cause a decrease in the poverty rate by -0.452933 percent with the assumption that the other variables are constant. This finding of this study is in line with studies conducted by Pratama (2014), Fadlillah et al. (2016), Yolanda (2017), and Wijaya $\mathrm{H}$ et al. (2020), stating that HDI has a negative and significant effect on the poverty rate

Meanwhile, total population has a coefficient of 2.144701, meaning that every one percent increase in population will cause an increase in the poverty rate by 2.144701 percent with the assumption that other variables are constant. This finding is in line with studies conducted by Mustika (2011), Azizah et al. (2018), stating that total population has a positive impact on poverty rate.

GRDP has a coefficient of -2.565675 , meaning that every one percent increase in GRDP will cause a decrease in the poverty rate by 2.565675 percent with the assumption that other variables are constant. The finding of this study is in line with the findings of Mustika (2011), Wahyuningsih \& Zamzami (2014), Silastri (2017), and Wijaya et al. (2020), stating that GRDP has a negative and significant effect on poverty rate. Meanwhile, the impact of the Covid-19 pandemic has a coefficient of 0.536672 , meaning that the presence of Covid-19 pandemic causes an increase in the poverty rate by 0.536672 percent, assuming that other variables are constant.

\section{CONCLUSION}

Based on the results and discussion, this study comes to the following conclusions: (1) In 2020, the percentage of people living in poverty in Central Java increased by 0.61 percent compared to 2019 . (2) The Random Effect Model (REM) was the best model to analyze the factors affecting poverty rate in Central Java. (3) The variables of HDI, GRDP, and the impact of Covid-9 partially had a significant effect on the poverty rate. (4) Total population had no significant effect on the poverty rate. (5) Poverty is a multidimensional problem that requires extra efforts to eradicate. However, the results of this 
study highlighted the strong relationship between poverty rate and the Covid-19 pandemic, GRDP, as well as education, health, and poverty through HDI. (6) We recommended further study to have more independent variables or use other analytical methods to find out factors affecting the poverty rate in Central Java.

\section{ACKNOWLEDGEMENT}

We express our deepest gratitude to Mr. Sentot Bangun Widoyono M.A. and Mr. Isnaini SST, M.M., who has provided the opportunity to the author to conduct this study. The author hopes the results of this study will be helpful for the nation.

\section{REFERENCES}

Alvitiani, S. (2019), Pemodelan Data Kemiskinan Provinsi Jawa Tengah Menggunakan Fixed Effect Spatial Durbin Model. Jurnal Gaussian. Vol. 8 No. 2.

Arsyad, L. (1999). Pengantar Perencanaan dan Pembangunan Ekonomi Daerah. Edisi pertama. Yogyakarta: BPFE.

Azizah EW, Sudarti, \& Kusuma H (2018), Pengaruh Pendidikan, Pendapatan Perkapita Dan Jumlah Penduduk Terhadap Kemiskinan Di Provinsi Jawa Timur, Jurnal Ilmu Ekonomi. Vol 2 Hal. 167-180.

Baltagi, B.H. (2005). Econometrics Analysis of Panel Data. [3rd ed.]. England (GB): John Wiley and Sons. BPS. (2020). Statistik Indonesia 2020. Retrieved from https://www.bps.go.id.

Darsyah, M. Y., Wasono R., \& Agustina, M.F. (2015), Pemodelan MGWR Pada Tingkat Kemiskinan di Provinsi Jawa Tengah. Value Added. Vol. 11, No. 1.

Didu, S. dan Fauzi, F. (2016), Pengaruh Jumlah Penduduk, Pendidikan Dan Pertumbuhan Ekonomi Terhadap Kemiskinan Di Kabupaten Lebak. Jurnal Ekonomi-Qu. Vol. 6 No. 1.

Fadlillah, N., Dewi, A.S. \& Sukiman, (2016), Analisis Pengaruh Pendapatan Per Kapita, Tingkat Pengangguran, IPM Dan Pertumbuhan Penduduk Terhadap Kemiskinan Di Jawa Tengah Tahun 2009-2013. Eko-Regional, Vol.11 No.1.

Indriani, L. \& Setiyono (2018), Analisis Kemiskinan Multidimensi Di Provinsi Jawa Tengah 2011-2013. Jurnal Aplikasi Statistika \& Komputasi Statistik. Vol.10 No 2.

Mustika, C. (2011), Pengaruh Produk Domestik Bruto dan Jumlah Penduduk Terhadap Kemiskinan di Indonesia Periode 1990-2008. Jurnal Paradigma Ekonomika. Vol.1 No. 4.

Nugroho, Iwan \& Dahuri, R. (2012). Pembangunan Wilayah Perspektif Ekonomi, Sosial, dan Lingkungan. Jakarta: LP3ES.

Pratama, C.Y. (2014). Analisis faktor faktor yang mempengaruhi kemiskinan di Indonesia. Bisnis dan Manajemen. Vol. 4 No. 2.

Rahmawati, R., Safitri, R.D., \& Fairuzdhiya, O.U. (2015), Analisis Spasial Pengaruh Tingkat Pengangguran Terhadap Kemiskinan Di Indonesia (Studi Kasus Provinsi Jawa Tengah). Media Statistika. Vol. 8 No. 1.

Saputra, WA. (2011). Analisis Pengaruh Jumlah Penduduk, PDRB, Ipm, Pengangguran terhadap Tingkat Kemiskinan di Kabupaten/Kota Jawa Tengah. Skripsi. Fakultas Ekonomi Universitas Diponegoro, Semarang.

Silastri, N. (2017). Pengaruh Jumlah Penduduk dan Pendapatan Domestik Regional Bruto (PDRB) Terhadap Kemiskinan di Kabupaten Kuantan Singingi. JOM Fekon. Vol. 4 No. 1.

Susanty, S. (2013). Pengaruh Produk Domestik Regional Bruto, Pengangguran dan Indeks Pembangunan Manusia terhadap Kemiskinan di Jawa Barat dengan Menggunakan Analisis Data Panel. Jurnal Matematika Integratif. Vol. 9 No. 1.

Tarigan, H., Sinaga, JH., \& Rachmawati, RR. (2020), Dampak Pandemi Covid-19 terhadap Kemiskinan di Indonesia. Dampak Pandemi Covid-19: Perspektif Adaptasi dan Resiliensi Sosial Ekonomi Pertanian. Hal. 457-479.

Todaro, Michael P., \& Stephen CS. (2000), Pembangunan Ekonomi. Edisi Kesembilan. Terjemahan oleh Harus Munandar, 2006. Jakarta: Erlangga. 
Wahyuningsih, YE., \& Zamzami, Z. (2014). Analisis Pengaruh Produk Domestik Regional Bruto dan Jumlah Penduduk Terhadap Tingkat Kemiskinan di Kabupaten Nagan Raya. Jurnal Ekonomi dan Kebijakan Publik Indonesia. Vol. 1 No. 1.

Widarjono A. 2009. Ekonometrika Pengantar dan Aplikasinya. Ekonosia. Yogyakarta.

Wijaya, H., Istiqomah \& Arintoko (2020), Analisis Faktor - Faktor yang Mempengaruhi Kemiskinan (Studi Kasus di Kabupaten Banjarnegara, Cilacap, Purbalingga, Kebumen, dan Banyumas). Jurnal IImiah Universitas Batanghari Jambi. Vol. 20 No. 2.

Yolanda, Y. (2017). Analysis of Factors Affecting Inflation and its Impact on Human Development Index and Poverty in Indonesia. European Research Studies Journal. Vol. 20 No. 4. 